\title{
PENGARUH DOSIS PUPUK ORGANIK DAN POPULASI ITIK TERHADAP PRODUKSI PADI PADA SISTEM INTEGRASI PADI DAN ITIK
}

\section{THE EFFECT OF DOSAGE OF ORGANIC FERTILIZER AND DUCK POPULATION ON RICE PRODUCTION IN RICE AND DUCK INTEGRATION SYSTEMS}

\author{
Achmad Nizar dan Budianto \\ Politeknik Pembanguan Pertanian Malang \\ email: achmad.nizar@polbangtanmalang.ac.id
}

\begin{abstract}
ABSTRAK
Penelitian bertujuan untuk mengetahui pertumbuhan dan produksi serta interaksi antara dosis pupuk organik dan populasi itik terhadap pertumbuhan dan produksi padi. Penelitian dilaksanakan pada Bulan September sampai dengan Desember 2017. Lokasi penelitian di Sekolah Tinggi Penyuluhan Pertanian Malang. Penelitian menggunakan rancangan acak kelompok dengan 2 faktor. Faktor 1 adalah dosis pupuk organik (P1). Dosis 10 ton /ha, P2). 20 ton /ha, dan P3). 30 ton /ha) sedangkan Faktor 2 adalah Populasi itik (B0). Tanpa itik, B1). 1 ekor/5m2. Setiap perlakuan diulang 4 kali. Parameter yang diamati: a).Tinggi tanaman, b). Jumlah anakan produktif, c). Berat gabah kering panen, dan d). berat gabah kering giling. Hasil penelitian menunjukkan Perlakuan dosis pupuk organik 30 ton /ha mempengaruhi jumlah anakan, berat gabah kering panen, dan berat gabah kering giling secara nyata, sedangkan perlakuan populasi itik tidak mempengaruhi jumlah anakan, berat gabah kering panen dan berat gabah kering giling. Berdasarkan analisis tidak ada interaksi antara dosis pupuk organik dengan populasi itik pada pertumbuhan dan produksi padi.
\end{abstract}

Kata Kunci: padi, itik, pupuk organik

\begin{abstract}
The research aims to determine the growth and production as well as the interaction between the dosage of organic fertilizer and duck population on rice growth and production. The research was conducted from September to December 2017. The research sites were in Malang Agricultural Extension College. The study used a randomized block design with 2 factors. Factor 1 is the dose of organic fertilizer (P1). The dosage of 10 tons / ha, P2). 20 tons / ha, and P3). 30 tons / ha. While Factor 2 was the duck population (B0). Without duck, B1).1 duck/ 5m2. Each treatment was repeated 4 times. Parameters observed: a). Plant height, b). Number of productive tillers, c). dry grain weight of harvest, and d). dry grain weight milled. The results showed that the treatment of organic fertilizer dosage of 30 tons / ha affected the number of tillers, dry grain weight of harvested, and milled dry grain weight significantly, while the treatment of duck population did not affect the number of tillers, harvested dry grain weight and dry milled grain weight. Based on the analysis there was no interaction between organic fertilizer doses and duck populations on rice growth and production.
\end{abstract}

Key words: rice, duck, organic fertilizer

74 | Jurnal Agriekstensia Vol 18 No. 1 Juli 2018 


\section{PENDAHULUAN}

Budidaya padi dan itik merupakan salah satu teknologi pertanian terpadu yang didalamnya ada padi dan itik yang dibudidayakan pada lahan yang sama. Keuntungan yang diperoleh dengan penerapan budidaya padi dan itik adalah: a. Manfaat untuk penyiangan, $b$. Manfaat pengendalian hama penyakit, c. Manfaat pemupukan, d. Manfaat pembajakan dan penggemburan tanah sepanjang waktu, e. Manfaat mengendalikan keong emas, dan f. Manfaat stimulasi pertumbuhan padi (Hossain et al 2005). Selanjutnya dilaporkan dengan menerapkan pertanian terpadu padi dan itik ada beberapa keuntungan diantaranya Keuntungan langsung: a. Produksi padi sistim padi dan itik relatif tidak menurun hasilnya dibandingkan dengan sistem usahatani padi saja, b. Telur dan daging itik merupakan nilai tambah bagi pendapatan petani, c. Kesejahteraan dan pendapatan petani meningkat.

Sedangkan Keuntungan tidak langsung: (a) penyerapan tenaga kerja meningkat sepanjang musim padi dan setelah musim padi, sehingga dapat mengurangi pengangguran; (b) protein hewani tersedia sepanjang musim bagi masyarakat pedesaan; (c) terjadi daur ulang yang saling menguntungkan, yaitu itik dapat menekan populasi gulma dan hama (pengendalian hayati); kotoran itik menjadi pupuk padi; itik berfungsi sebagai pabrik untuk meningkatkan nilai tambah dari gabah yang hilang pada saat panen.

Pupuk organik sangat bermanfaat bagi peningkatan produksi pertanian baik kualitas maupun kuantitas, mengurangi pencemaran lingkungan, dan meningkatkan kualitas lahan secara berkelanjutan. Penggunaan pupuk organik dalam jangka panjang dapat meningkatkan produktivitas lahan dan dapat mencegah degradasi lahan (Clark M. Sean 2017).
Sumber bahan untuk pupuk organik sangat beranekaragam, dengan karakteristik fisik dan kandungan kimia yang sangat beragam sehingga pengaruh dari penggunaan pupuk organik terhadap lahan dan tanaman dapat bervariasi. Selain itu, peranannya cukup besar terhadap perbaikan sifat fisika, kimia, dan biologi tanah serta lingkungan. Pupuk organik yang ditambahkan ke dalam tanah akan mengalami beberapa kali fase perombakan oleh mikroorganisme tanah untuk menjadi humus. Bahan organik juga berperan sebagai sumber energi dan makanan mikroba tanah sehingga dapat meningkatkan aktivitas mikroba tersebut dalam penyediaan hara tanaman.

Hasil-hasil penelitian menunjukkan bahwa penanaman terus menerus dan dilaksanakan secara intensif serta semua hasil panen diangkut keluar lahan akan mengakibatkan sebagian besar lahan sawah berkadar bahan organik rendah (C-organik < 2\%). Mundaa Sushmita et al (2017) menyatakan sekitar $60 \%$ dari lahan sawah mempunyai kandungan bahan organik (Corganik) yang sangat rendah. Rendahnya kandungan C-organik di dalam tanah sawah akan memberikan pengaruh negatif terhadap produktivitas padi sawah. Selanjutnya menurut Gongab Ruyu et al 2018, terdapat korelasi positif antara kandungan C-organik tanah dengan produktivitas padi sawah, dimana semakin rendah kandungan C-organik tanah semakin rendah produktivitas tanaman padi sawah. Eghball Bahman dan Powera James F. (2017) menyatakan bila kandungan C-organik tanah besar dari $2 \%$, maka tanpa pupuk anorganik hasil panenan padi sawah sudah dapat mencapai lebih dari empat ton per hektar. Akan tetapi bila kandungan C-organik tanah kurang dari satu persen, untuk memperoleh hasil panen yang sama dibutuhkan tambahan pupuk anorganik lengkap (Urea, TSP, dan $\mathrm{KCl}$ ) dengan takaran yang cukup tinggi. 
Sistim Pertanian Terpadu merupakan sistem yang menggabungkan kegiatan pertanian, peternakan, perikanan dan lainnya yang terkait dengan pertanian dalam satu lahan yang sama. Dengan adanya sistim pertanian terpadu diharapkan dapat nnnmenjadi salah satu solusi untuk meningkatkan produktivitas lahan. Pada hakikatnya pertanian terpadu adalah memanfaatkan seluruh potensi energi sehingga dapat dipanen secara seimbang. Selain hemat energi, keunggulan lain dari pertanian terpadu adalah petani akan memiliki beragam sumber penghasilan (S M. Gill, et al, 2018), dan (Devendraa C dan D Thomasb 2017). Tujuan penelitian ini adalah untuk mngetahui pertumbuhan dan produksi padi dan mengetahui interaksi antara dosis pupuk organik dan populasi itik terhadap pertumbuhan dan produksi padi.

\section{METODE PENENLITIAN}

\section{Waktu dan Tempat}

Penelitian dilaksanakan pada Bulan September sampai dengan Desember 2017. Lokasi penelitian di Lahan praktek Sekolah Tinggi Penyuluhan Pertanian Malang kampus I. Jalan Dr.Cipto 144A Bedali Lawang Malang.

\section{Alat dan Bahan}

Alat yang digunakan pada penelitian adalah: traktor roda 2, cangkul, Lempak, sabit meteran dan timbangan. Bahan yang digunakan adalah: benih padi, bibit itik, pupuk organik, pakan itik, plastik, karung plastik, bambu.

\section{Pelaksanaan}

Luas lahan yang digunakan penelitian adalah $1000 \mathrm{~m}^{2}$. Lahan berpengairan teknis. Sebelum penanaman padi tanah dibajak dengan menggunakan traktor roda 2. Luas petak percobaan adalah $40 \mathrm{~m}^{2}$. Pada setiap petak percobaan dibuat pematang dan saluran irigasi untuk air masuk dan keluar dari petak percobaan. Setiap petak percobaan dipasang plastik pemisah. Tujuan pemasangan plastik pemisah adalah untuk menghidari itik agar tidak keluar dari petak percobaan. Pupuk organik sebagai perlakuan diberikan setelah pembuatan petak percobaan selesai.

Benih padi disemai dengan menggunakan sistem dabog, yaitu persemaian padi diberi alas plastik dan diatasnya diberi lumpur setinggi $2 \mathrm{~cm}$. Pada umur 21 hari benih padi ditanam di petak percobaan. Penanaman padi menggunakan system jajar legowo 2:1.

Kandang itik dibuat dari bambu dengan ukuran panjang $2 \mathrm{~m}$ lebar $1 \mathrm{~m}$. Atap kandang terbuat dari terpal plastik. Itik yang digunakan penelitian berumur 2 bulan, sebelum dilepas di petak percobaan, itik dilatih terlebih dahulu untuk menyesuaikan lingkungannya yang baru.

Perawatan tanaman padi adalah: pengairan, dilakukan dengan cara pengairan basah kering, sedangkan perawatan itik adalah memberi makan sesuai dengan takaran pakan kebutuhan itik.

Penelitian menggunakan rancangan acak kelompok dengan 2 faktor. Faktor 1 adalah dosis pupuk organik (P1). Dosis 10 ton /ha, P2). 20 ton /ha, dan P3). 30 ton /ha) sedangkan Faktor 2 adalah Populasi itik (B0). Tanpa itik, B1). 1 ekor/5m2. Setiap perlakuan diulang 4 kali. Parameter yang diamati: jumlah produksi padi dan berat badan itik. Analisa data menggunakan analisa kovarian, bila ada perbedaan diuji beda nyata menggunakan Duncan pada taraf 5\%. Kombinasi perlakuan sebagai berikut: 1. P1B0, 2. P1B1, 3.P2B0, 4.P2B1, 5.P3B0, dan 6.P3B1.

Sampel pengamatan dipilih secara acak. Jumlah sampel yang digunakan ditentukan sebanyak $20 \%$ dari populasi rumpun padi di setiap petak percobaan. Parameter yang diamati adalah: 1. Tinggi tanaman padi, 2. Jumlah anakan produktif per rumpun sampel. 3. Berat gabah kering panen 
setiap petak percobaan. 4. Berat gabah kering giling pada setiap petak percobaan. Data percobaan dianalisis secara anova covarian dengan menggunakan SPSS. Apabila ada perbedaan diuji beda terkecil dengan taraf $5 \%$.

\section{Tinggi Tanaman}

\section{HASIL DAN PEMBAHASAN}

Tinggi tanaman dapat dibaca pada Tabel 2 dibawah ini:

Tabel 1. Rata rata Tinggi Tanaman Padi Varietas Ciherang Pada Perlakuan Dosis

Pupuk Organik dan Populasi Itik

\begin{tabular}{ccc}
\hline No & Perlakuan & Tinggi Tanaman $(\mathrm{cm})^{*}$ \\
\hline 1 & P1B0 & $117 \mathrm{a}$ \\
2 & P1B1 & $116 \mathrm{a}$ \\
3 & P2B0 & $117 \mathrm{a}$ \\
4 & P2B1 & $118 \mathrm{a}$ \\
5 & P3B0 & $116 \mathrm{a}$ \\
6 & P3B1 & $117 \mathrm{a}$ \\
\hline
\end{tabular}

* Angka rerata yang diikuti huruf yang berbeda pada kolom sama menunjukkan berbeda nyata pada uji BNT $5 \%$.

Pada Tabel 1 diatas menunjukkan tidak ada perbedaan tinggi tanaman pada masing masing perlakuan, sehingga dapat dikatakan perlakuan dosis pupuk organic dan populasi Itik tidak mempengaruhi tinggi tanaman padi varietas Ciherang.

\section{Jumlah Anakan produktif}

Jumlah anakan produktif dapat dibaca pada Tabel 2 dibawah ini:

Tabel 2. Jumlah Anakan Produktif Pada Setiap Sampel Pengamatan

\begin{tabular}{ccc}
\hline No & Perlakuan & $\begin{array}{c}\text { Jumlah Anakan Produktif } \\
\text { per Sampel (Rumpun)* }\end{array}$ \\
\hline 1 & P1B0 & $14 \mathrm{a}$ \\
2 & P1B1 & $14 \mathrm{a}$ \\
3 & P2B0 & $15 \mathrm{a}$ \\
4 & P2B1 & $16 \mathrm{a}$ \\
5 & P3B0 & $20 \mathrm{~b}$ \\
6 & P3B1 & $20 \mathrm{~b}$ \\
\hline
\end{tabular}

* Angka rerata yang diikuti huruf yang berbeda pada kolom sama menunjukkan berbeda nyata pada uji BNT $5 \%$.

77 | Jurnal Agriekstensia Vol. 18 No. 1 Juli 2019
Jumlah anakan produktif menunjukkan ada perbedaan yang nyata, yaitu pada perlakuan dosis pupuk 30 ton per hektar mampu menghasilkan jumlah anakan produktif lebih tinggi apabila dibandingkan dengan perlakuan yang lain. Perlakuan populasi itik tidak mempengaruhi jumlah anakan. Hal ini diduga kandungan unsur hara pada pupuk organik yang diberikan pada dosis 30 ton per ha mampu memicu tanaman padi varietas Ciherang menghasilkan anakan lebih banyak dibandingkan perlakuan dosis pupuk 1 dan 2 ton per ha.

\section{Produksi Gabah Kering Panen}

Produksi gabah kering panen disajikan pada Tabel 3 di bawah ini:

Tabel 3. Produksi Gabah Kering Panen Pada

Perlakuan Dosis Pupuk Organik dan Populasi Itik per Petak Percobaan

No Perlakuan Produksi Gabah Kering

Panen $(\mathrm{kg}) *$

$\begin{array}{lll}1 & \text { P1B0 } & 21 \mathrm{a} \\ 2 & \text { P1B1 } & 23 \mathrm{a} \\ 3 & \text { P2B0 } & 25 \mathrm{a} \\ 4 & \text { P2B1 } & 26 \mathrm{a} \\ 5 & \text { P3B0 } & 30 \mathrm{~b} \\ 6 & \text { P3B1 } & 30 \mathrm{~b}\end{array}$

* Angka rerata yang diikuti huruf yang berbeda pada kolom sama menunjukkan berbeda nyata pada uji BNT $5 \%$.

Produksi padi tertinggi dihasilkan pada perlakuan dosis pupuk 30 ton per ha, sedangkan populasi itik tidak berpengaruh nyata pada peningkatan produksi padi. Dosis pupuk organik dapat meningkatkan berat kering panen. Hal ini diduga jumlah pupuk organik memberikan unsur hara yang cukup buat tanaman padi untuk menghasilkan gabah kering panen.

\section{Produksi Gabah Kering Giling}

Tabel 4 di bawah menunjukkan penambahan dosis 30 ton per ha mampu meningkatkan rendemen padi kering giling 
tertinggi bila dibandingkan dengan perlakuan dosis pupuk organik sebanyak 10 dan 20 ton per ha.

Tabel 4. Hasil Gabah Kering Giling per Petak Percobaan Perlakuan Dosis pupuk Organik dan Populasi Itik

\begin{tabular}{ccc}
\hline No & Perlakuan & $\begin{array}{c}\text { Produksi Gabah } \\
\text { Kering Giling }(\mathrm{kg})^{*}\end{array}$ \\
\hline 1 & P1B0 & $17.22 \mathrm{a}$ \\
2 & P1B1 & $18.86 \mathrm{a}$ \\
3 & P2B0 & $20.5 \mathrm{a}$ \\
4 & P2B1 & $21.32 \mathrm{a}$ \\
5 & P3B0 & $24.6 \mathrm{~b}$ \\
6 & P3B1 & $24.6 \mathrm{~b}$
\end{tabular}

* Angka rerata yang diikuti huruf yang berbeda pada kolom sama menunjukkan berbeda nyata pada uji BNT $5 \%$.

Perlakuan dosis pupuk organik dapat meningkatkan berat gabah kering giling secara nyata, sedangkan perlakuan populasi itik tidak mempengaruhi berat gabah kering giling.

\section{KESIMPULAN}

Penelitian pengaruh dosis pupuk organik dan populasi itik dalam system pertanian tepadu dapat disimpulkan sebagai berikut:

1. Perlakuan dosis pupuk organik dan populasi itik tidak mempengaruhi tinggi tanaman padi varietas Ciherang. Perlakuan pupuk dosis pupuk organik 30 ton /ha mempengaruhi jumlah anakan, berat gabah kering panen, dan berat gabah kering giling secara nyata, sedangkan perlakuan populasi itik tidak mempengaruhi jumlah anakan, berat gabah kering panen dan berat gabah kering giling.

2. Berdasarkan analisis data tidak ada interaksi antara dosis pupuk organik dengan populasi itik dalam sistem usaha tani terpadu padi dan itik dalam pertumbuhan dan produksi padi pada penelitian ini.

\section{DAFTAR PUSTAKA}

Devendraa D Thomasb. 2018. Smallholder farming systems in Asia. Agricultural Systems Volume 71, Issues 1-2, JanuaryFebruary 2002, Pages 17-25. https://www.sciencedirect.com/scien ce/article/pii/S0308521X01000336. (28-07-2017).

Bahman Eghball and James F. Powera.2018. Phosphorus- and Nitrogen-Based Manure and Compost Applications Corn Production and Soil Phosphorus. Soil Science Society of America Journal Abstract - DIVISION S-4SOIL FERTILITY \& PLANTNUTRITION.

https://dl.sciencesocieties.org/public ations/sssaj/abstracts/63/4/895. (28-07-2017).

Gill, M. S. ; Singh, J. P. ; Gangwar, K. S. 2018. Integrated farming system and agriculture sustainability. Indian Journal of Agronomy 2009 Vol.54 No.2 pp.128- 139 ref.30. https://www.cabdirect.org/cabdirect/ abstract/20093232138.(28-07-2017)

Hossain, Shaikh Tanveer; Sugimoto, Hideki; Ahmed, Gazi Jashim Uddin and Islam, Md. Rafiqul .2005. Effect of Integrated Rice-Duck Farming on Rice Yield, Farm Productivity, and Rice-Provisioning Ability of Farmers. Asian Journal of Agriculture and Development, 2 (1), pp. 79-86. 
Pengaruh Dosis Pupuk Organik dan Populasi Itik terhadap Produksi Padi .......

(Achmad Nizar dan Budianto)

http://orgprints.org/29178/. (28-072017).

Keith Paustian , William J. Parton and Jan Persso.2018. Modeling Soil Organic Matter in Organic-Amended and Nitrogen-Fertilized Long-Term Plots. https://dl.sciencesocieties.org/public ations/sssaj/abstracts/56/2/S S05600 20476. (28-07-2017)

Ruyu Gongab, Chunyue Aiab, Baojun Zhangabc, Xianglei Chengab. 2018. Effect of selenite on organic selenium speciation and selenium bioaccessibility in rice grains of two Se-enriched rice cultivars. https://www.sciencedirect.com/scien ce/article/pii/S0308814618308756. (28-07-2017).

M. Sean Clark, William R. Horwath, Carol Shennan and Kate M. Scow. 2018.
Changes in Soil Chemical

Properties Resulting from Organic and Low-Input Farming Practices. Agronomy Journal. https://dl.sciencesocieties.org/public ations/aj/abstracts/90/5/AJ09000506 62. (28-07-2017).

Sushmita Mundaa, Debarati Bhaduria, Sangita Mohantya, Dibyendu Chatterjeea, Rahul TripathiaM, Shahida Upendra, Kumara P. Bhattacharyyaa Anjani, KumaraTotan, Adakb Hemant, K. Jangdeac A, K. Nayaka. 2018. Dynamics of soil organic carbon mineralization and $C$ fractions in paddy soil on application of rice https://www.sciencedirect.com/scien ce/article/pii/S0961953418300850. (28-07-2017) 